Check for updates

Cite this: RSC Adv., 2019, 9, 39458

Received 21st October 2019

Accepted 25th November 2019

DOI: $10.1039 / \mathrm{c} 9 \mathrm{ra0} 8630 \mathrm{~g}$

rsc.li/rsc-advances

\section{Electrophilically activated nitroalkanes in reaction with aliphatic diamines en route to imidazolines $\uparrow$}

\author{
Alexander V. Aksenov, (D) *a Nicolai A. Aksenov, (D) ${ }^{a}$ Nikolai A. Arutiunov, ${ }^{a}$ \\ Vladimir V. Malyuga, ${ }^{\text {a }}$ Sergey N. Ovcharov ${ }^{a}$ and Michael Rubin (D)*ab
}

A novel synthetic methodology for the assembly of imidazolines via an unusual reaction between nitroalkanes and aliphatic 1,2-diamines in the presence of phosphorous acid is described. In contrast to the related highly efficient preparation of benzimidazoles from aromatic amines, this process represents a major synthetic challenge and for a long time was elusive. Analysis of the method limitations is provided.

\section{Introduction}

Compounds with a five membered cyclic amidine core isosteric to peptide bond, play a very important role in medicinal chemistry. Targeting adrenergic and imidazoline receptors these small molecules could show regulatory function for the central nervous system, and have found utility in the development of many marketed drugs for the treatment of hypertension, diabetes, neural disorders, etc. ${ }^{1,2}$ In addition, ligands with a 2-imidozaline structure were shown to target adenosine, ${ }^{3}$ cholecystokinin, ${ }^{4}$ cyclooxygenase- $2,{ }^{5}$ estrogen,${ }^{6}$ and histamine ${ }^{7}$ receptors. Also, molecules of this class were studied as inhibitors of DNA topoisomerase, ${ }^{8}$ proteasome, ${ }^{9}$ and cholesterol acyltransferase ${ }^{10}$ enzymes. Not surprisingly, imidazalines are often regarded nowadays as one of the privileged scaffolds for drug discovery. ${ }^{11,12}$ Normally, preparation of 2-imidazolines 4 is very straightforward and involves acylation of 1,2-diamines 2 with carbonyl compounds $\mathbf{1}$ (acyl, thioacyl, carbamoyl halides, esters, carboxylic acids, or nitriles) and subsequent cyclocondensation of the formed $\beta$-aminocarboxamide intermediate 3 (Scheme 1) ${ }^{13-16}$ For number of years we were interested in electrophilic activation of nitroalkanes and their reactions with different nucleophilic species. We pondered if this approach can be employed to access 2-imidazolines. Indeed, in this case, the reaction of diamines 2 with nitroalkanes 5 would provide $N$ hydroxyamidines $\mathbf{6}$, which after cyclization and elimination of hydroxylamine should afford the same core 4 . Herein we wish to report a full account of this investigation.

${ }^{a}$ Department of Chemistry, North Caucasus Federal University, 1a Pushkin St., Stavropol 355009, Russian Federation. E-mail: alexaks05@rambler.ru

${ }^{b}$ Department of Chemistry, University of Kansas, 1567 Irving Hill Road, Lawrence, KS 66045-7582, USA. E-mail: mrubin@ku.edu; Tel: +1-785-864-5071

$\dagger$ Electronic supplementary information (ESI) available. See DOI: $10.1039 / \mathrm{c} 9 \mathrm{ra} 08630 \mathrm{~g}$

\section{Results and discussion}

In recent years, our group has developed an expertise in designing novel acid-mediated multistep cascade transformations of nitroalkenes and nitroalkanes targeting material science and medicinal chemistry applications. In particular, it was shown that nitroalkanes 5 dissolved in polyphosphoric acid (PPA) transform into phosphorylated nitronate 7 showing strong electrophilic properties. This unusual species can be used to design a number of one-pot multi-step transformations involving various carbon-based nucleophiles. ${ }^{17-19}$ The utilization of nucleophilic amines was also demonstrated. ${ }^{20-24}$ Mechanistically, the latter process is related to the classical Nef reaction, ${ }^{25-27}$ employing aniline ${ }^{20-23}$ or hydrazine ${ }^{24}$ species 8 instead of water. It was proposed, that this reaction initially provides imidinium ion $\mathbf{9}$, that can be further employed as a convenient building block for the synthesis of heterocyclic
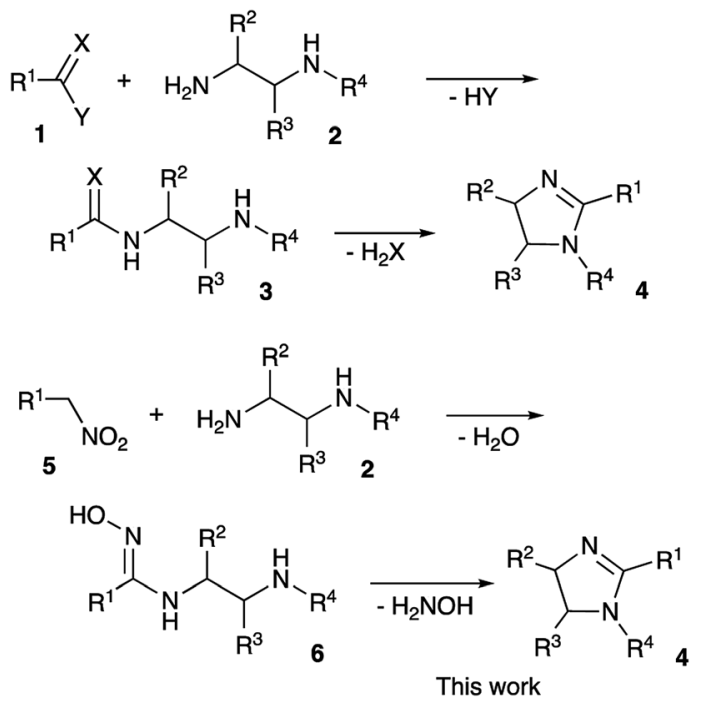

Scheme 1 Formation of imidazolines. 
compounds: benzoxazoles 10, benzimidazoles 11, diazines 1213, ${ }^{20-23}$ and oxadiazoles 14 (ref. 24) (Scheme 2). Evidently, employment of aliphatic 1,2-diamines in this synthetic scheme would potentially provide 2 -imidazolines 4 .

To test this idea, we stirred a mixture of 1-nitropropane (1a) and $N$-phenyl-1,2-ethylenediamine (2a) in $86 \%$ polyphosphoric acid (PPA with $86 \% \mathrm{P}_{2} \mathrm{O}_{5}$ content, an equivalent of polymeric metaphosphoric acid) under conditions previously optimized for synthesis of benzimidazoles. ${ }^{20}$ Upsettingly, we failed to observe formation of any imidazolines at $130{ }^{\circ} \mathrm{C}$ (Table 1 , entry 1), and only traces of the desired product $4 \mathbf{a a}$ were detected in

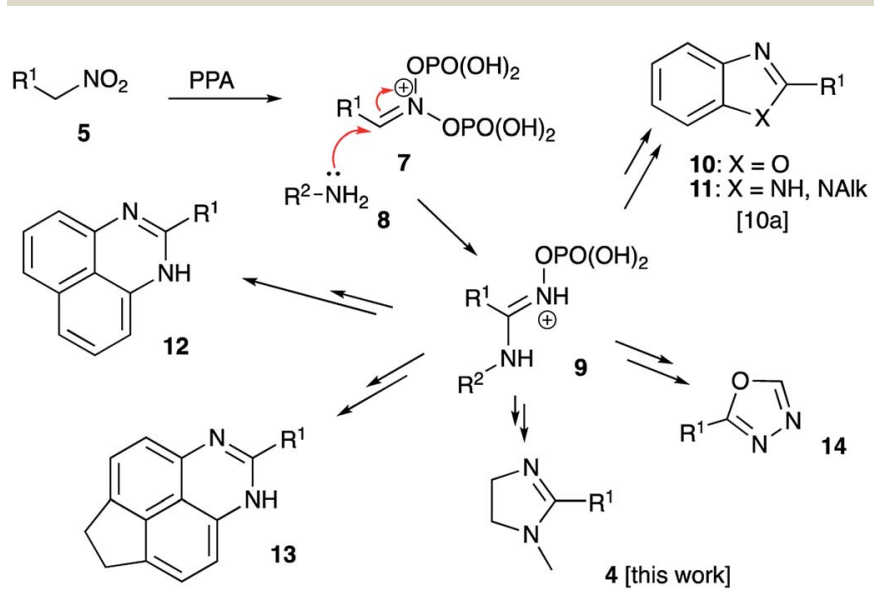

Scheme 2 Activation of nitroalkanes towards nucleophilic attack by amines.

Table 1 Optimization of reaction conditions for cyclocondensation of $1 \mathrm{a}$ and $2 \mathrm{a}$ to produce imidazoline $4 \mathrm{aa}$
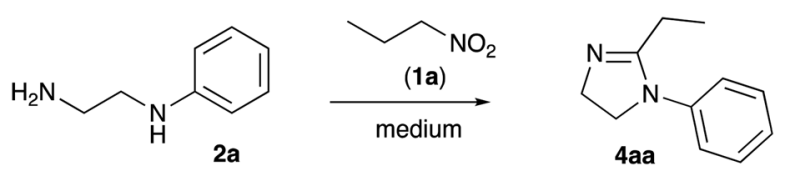

Medium

PPA $86 \%(2 \mathrm{~g})$

PPA $86 \%(2 \mathrm{~g})$

PPA $80 \%(2 \mathrm{~g})$

PPA $80 \%(2 \mathrm{~g}), \mathrm{PCl}_{3}(0.5 \mathrm{~g})$

PPA $80 \%$ (0.5 g), EtOH $(1 \mathrm{~mL})$

$\mathrm{PCl}_{3}(0.5 \mathrm{~g})$, xylene $(1 \mathrm{~mL})$

$\mathrm{H}_{3} \mathrm{PO}_{4} 100 \%(2 \mathrm{~g})$

$\mathrm{H}_{3} \mathrm{PO}_{4} 86 \%(2 \mathrm{~g})$

$\mathrm{HCOOH}(0.5 \mathrm{~mL})$

$10 \mathrm{AcOH}(0.5 \mathrm{~mL}), \mathrm{TsOH} \cdot \mathrm{H}_{2} \mathrm{O}(190 \mathrm{mg})$

$1 \mathrm{TsOH} \cdot \mathrm{H}_{2} \mathrm{O}(95 \mathrm{mg})$, $\mathrm{PhCl}(2 \mathrm{~mL})$

$12 \mathrm{H}_{3} \mathrm{PMo}_{12} \mathrm{O}_{40}(50 \mathrm{mg}), \mathrm{PhCl}(2 \mathrm{~mL})$

13 PPA 86\% (1.5 g), $\mathrm{H}_{3} \mathrm{PO}_{3}(0.5 \mathrm{~g})$

14 PPA $86 \%(1.5 \mathrm{~g}), \mathrm{H}_{3} \mathrm{PO}_{3}(0.5 \mathrm{~g})$

15 PPA 86\% (0.5g), $\mathrm{H}_{3} \mathrm{PO}_{3}(0.5 \mathrm{~g})$

$16 \mathrm{H}_{3} \mathrm{PO}_{3}(0.5 \mathrm{~g})$

${ }^{a}$ NMR yield of compound 4 aa are shown; test reactions were performed in $1.0 \mathrm{mmol}$ scale. the reaction mixture heated at $170{ }^{\circ} \mathrm{C}$. Next we tested reaction mediated by $80 \%$ PPA (an equivalent of relatively strong pyrophosphoric acid, $\mathrm{H}_{4} \mathrm{P}_{2} \mathrm{O}_{7}$ ), which also failed to provide imidazoline product neat (entry 3 ) or in the presence of activating additives: $\mathrm{PCl}_{3}$ (entry 4) or $\mathrm{EtOH}$ (entry 5). We also failed to observe any reactivity towards formation of 4aa after heating the reagents in the presence of $\mathrm{PCl}_{3}$ in boiling xylene (entry 6). Our attempts on carrying the reaction in orthophosphoric acid, either anhydrous (entry 7 ) or commercial 86\% aqueous (entry 8 ) proved to be a total fiasco as well. Frustrated with this long series of failures, we started to test the possibility to cyclize the imidazoline core in the presence of other strong Brønsted acids, which ever were used for electrophilic activation of nitroalkanes or nitroalkenes in our laboratories: formic (entry 9), tosic acid in protic (entry 10) or aprotic (entry 11) solvents, and even phosphomolybdic acid (HPA, entry 12), but the stubborn reaction newer worked. We saw the light at the end of the tunnel when one of the test reactions carried out at $170{ }^{\circ} \mathrm{C}$ in $86 \%$ PPA in the presence of phosphorous acid additive afforded $56 \%$ of the desired product (entry 13). Further improvement was achieved after lowering the reaction temperature. The process took longer time for completion, but provided improved yield (entry 14). We also noticed, that reaction is being mediated by $\mathrm{H}_{3} \mathrm{PO}_{3}$ namely, while molten PPA serves as polar solvent with slight adverse effect. Indeed, an attempt to reduce the amount of PPA in the mixture led to the further improvement of the reaction outcome (entry 15). Finally, we discovered that the process is best mediated by $\mathrm{H}_{3} \mathrm{PO}_{3}$ alone under solvent-free conditions (entry 16).

With optimized conditions in hands, we proceeded with evaluation of preparative value of this reaction. After standard aqueous quench and neutralization of the reaction mixture with aqueous ammonia, crude 4 aa could be routinely extracted and purified by preparative column chromatography to afford pure product in $74 \%$ yield (Scheme 3 , entry 1 ). Ethylenediamines $\mathbf{2 b}$ and 2c bearing $N$ - $p$-anisyl and $N$-benzyl substituents, respectively, were also tested in reaction with 1-nitropropane (1a) to provide the corresponding products $\mathbf{4 a b}$ and $\mathbf{4 a c}$ in comparable yields (entries 2, 3). An attempt to use 1,2-propylenediamine (2d) possessing two primary amino groups proved more challenging. In this case yield of product 4 ad was quite marginal (entry 4), probably due to significant losses of quite volatile starting material at elevated temperatures despite efficient reflux condenser employed. Another factor affecting the yield could be a sensitivity of the reaction to the steric hindrance at $\mathrm{C}$ 1. Indeed, in the reaction of non-volatile diamine $2 \mathrm{e}$ bearing even bulkier $\mathrm{Ph}$ group at $\mathrm{C}-1$, the yield was also quite low (entry 5).

It should be pointed out that volatility of the starting materials escaping the reaction vessel seems to be a major challenge to be addressed in the design of this process. Although this is expected to become a less of an issue upon scale up, in $1.0 \mathrm{mmol}$ scale this has an adverse effect on the reaction performance. Indeed, all reactions involving nitroethane $\mathbf{1} \mathbf{b}, \mathbf{b p}$ $115^{\circ} \mathrm{C}$ ) provided consistently lower yields than those carried out in the presence of 1-nitropropane (1a, bp $132{ }^{\circ} \mathrm{C}$ ) (Scheme 3, entries 6-8). This problem becomes a nuisance when trying to 


$$
\underbrace{\mathrm{R}_{2}}_{2}
$$
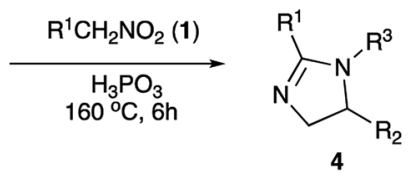

$$
\begin{aligned}
& \text { 1a: } \mathbf{R}^{1}=\mathrm{Et} ; \\
& \text { 1b: } \mathbf{R}^{1}=\mathrm{Me} ; \\
& \text { 1c: } \mathbf{R}^{1}=\mathrm{H} ; \\
& \text { 1d: } \mathbf{R}^{1}=n-\mathrm{C}_{7} \mathrm{H}_{15} ; \\
& \text { 1e: } \mathbf{R}^{1}=\mathrm{PhCH}_{2} ; \\
& \text { 1f: } \mathbf{R}^{1}=\mathrm{Ph} ;
\end{aligned}
$$

2a: $R^{2}=H, R^{3}=P h$

2b: $\mathrm{R}^{2}=\mathrm{H}, \mathrm{R}^{3}=4-\mathrm{MeOC}_{6} \mathrm{H}_{4}$;

2c: $\mathrm{R}^{2}=\mathrm{H}, \mathrm{R}^{3}=\mathrm{PhCH}_{2}$;

2d: $\mathrm{R}^{2}=\mathrm{Me}, \mathrm{R}^{3}=\mathrm{H}$;

2e: $R^{2}=R^{3}=P h$<smiles>CCC1=NCCN1c1ccccc1</smiles>

(1) 4 aa: $74 \%$<smiles>CCC1=NCC(c2ccccc2)N1c1ccccc1</smiles>

(5) $4 \mathrm{ae}: 37 \%$<smiles>CCCN1CCN=C1CCOC</smiles>

(2) $4 \mathrm{ab}: 56 \%$<smiles>CC1=NCCN1c1ccccc1</smiles>

(6) $4 \mathrm{ba}: 62 \%$

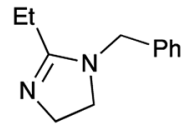

(3) $4 \mathrm{ac}: 77 \%$

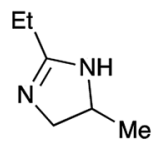

(4) $4 \mathrm{ad}: 38 \%$<smiles>COCCN1CCN=C1C</smiles>

(7) $4 \mathrm{bb}: 42 \%$<smiles>CC1=NCCN1Cc1ccccc1</smiles>

(8) 4 bc: $59 \%$<smiles>C1=NCCN1c1ccccc1</smiles>

(9) $4 \mathrm{ca}: 28 \%$<smiles>CCCC1=NCCN1CCOC</smiles>

(10) $4 d b: 53 \%$

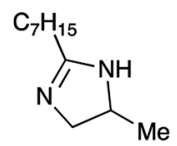

(11) $4 \mathrm{dd}$ : $43 \%$<smiles>c1ccc(CC2=NCCN2c2ccccc2)cc1</smiles>

(12) 4 ea: $41 \%$<smiles>c1ccc(C2=NCCN2c2ccccc2)cc1</smiles>

(13) 4 fa: $18 \%$<smiles>COCCN1CCN=C1c1ccccc1</smiles>

(14) 4fb: $16 \%$
Scheme 3 Synthesis of imidazolines.

synthesize imidazoline 4ca non-substituted at C-2 from nitromethane (1c, bp $\left.100-102^{\circ} \mathrm{C}\right)$. The yield obtained in this reaction was extremely poor even when we attempted to offset the loss by loading large excess (5 equiv.) of the reagent (entry 9). In contrast, reaction of high boiling nitroalkanes $1 \mathbf{d}$ and 1e proceeded smoothly, providing the corresponding cyclic products 4db, 4dd, and 4ea in moderate yields (entries 10-12).

Unexpectedly, we met a major challenge trying to employ $\alpha$ nitrotoluene (1f) as an electrophilic component of the featured transformation. The reaction was very sluggish, did not proceed to completion, and afforded very poor yields (Scheme 3, entries 13-14). An attempt to carry out this process under more forcing conditions did not lead to improvement, as the products notably decomposed at elevated temperatures. Evidently, in this case, steric issues become greatly prohibitive.

The mechanistic rationale of the described transformation is shown in Scheme 4. Initially, under acidic conditions nitroalkane 1 produces an aci form, which could be stabilized in phosphorylated nitronate form 15. As shown previously, both PPA and $\mathrm{H}_{3} \mathrm{PO}_{3}$ enable this step, but diphosphite 15 is less sterically hindered and usually more reactive than diphosphate analog derived from PPA. ${ }^{28}$ Nucleophilic attack by $\mathrm{NH}_{2}$-moiety of diamine 2 at C-1 of aci-form would first afford aminal 16,
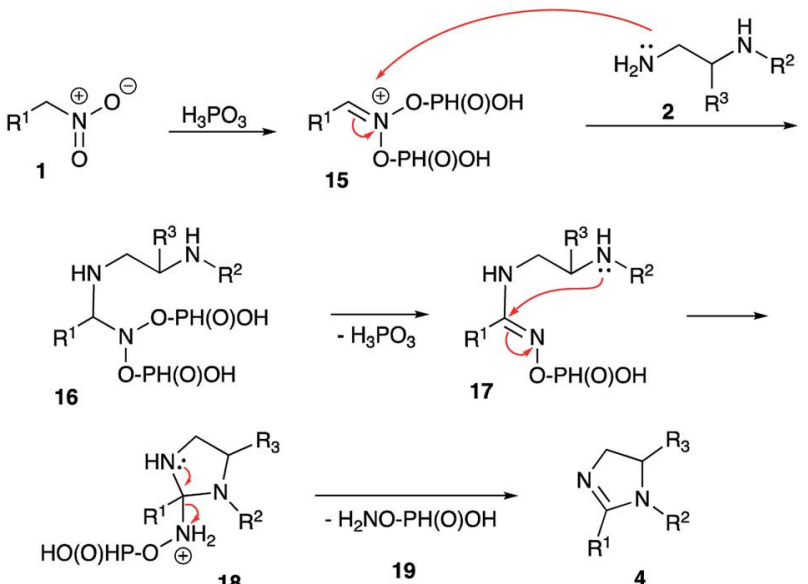

$-\mathrm{H}_{2} \mathrm{NO}-\mathrm{PH}(\mathrm{O}) \mathrm{OH}$

19<smiles>[R]C1=NCC([R])N1[R]</smiles>
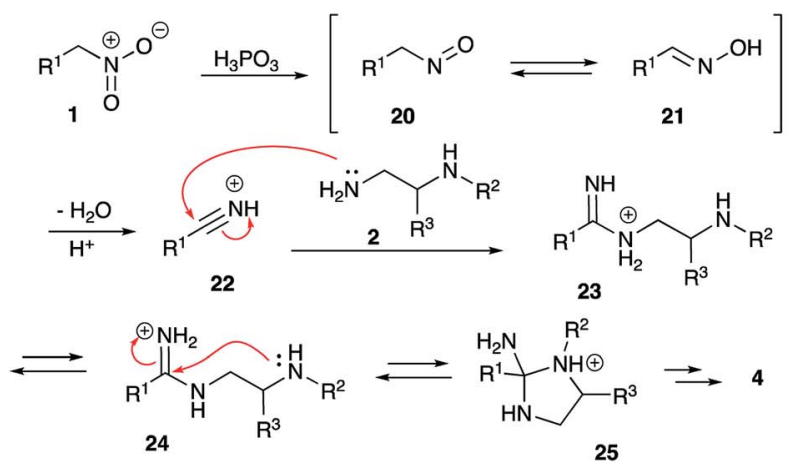

Scheme 4 Mechanistic rationales

which after subsequent elimination of phosphorus acid molecule would be transformed into amidine species 17 . The latter would experience 5-exo-trig nucleophilic attack by secondary amine moiety to produce intermediate triaminomethane 18 . This step is expected to be quite sensitive to steric factors, which explains poor results obtained in reactions involving reagents with relatively bulky substituents $R,{ }^{1} R^{2}$ and $R^{3}$. Finally, acidassisted elimination of hydroxylamine (in $O$-phosphorylated form 19) would yield imidazoline 4.

This rationale, however, cannot explain why orthophosphoric acid or PPA, which also are known to stabilize nitronate form via phosphorylation, did not mediate this cyclization. Taking into account, that phosphorous acid has distinct reducing properties, we pondered if this reagent could enable reduction of nitroalkanes into nitroso-compounds 20 (Scheme 4). Once formed, the later should tautomerize into oxime 21, which at elevated temperatures in the presence of acid would loose water to form nitrile (in highly electrophilic protonated form 22). Subsequent nucleophilic attack by primary amine group of diamine 2 shall produce amidinium ion, which exists in equilibrium between forms $\mathbf{2 3}$ and $\mathbf{2 4}$. Following 5-exo-trig cyclization 24 would afford cyclic triaminomethane species 25, which after elimination of ammonium molecule would yield imidazoline 4 (Scheme 4). It should be pointed out, that $\mathrm{H}_{3} \mathrm{PO}_{3}$ indeed seems to be able to reduce nitroalkanes under the featured reaction conditions. Thus, 
nitroethane was converted into acetonitrile, which in the absence of nucleophilic amines was further hydrolyzed into acetic acid and ammonia (both detected by mass spectroscopy). Interception of nitrile species the presence of benzylamine (26) afforded acetamide 27 in $80 \%$ (NMR yield) (Scheme 5).

Next, we attempted to synthesize 2-acyl-substituted imidazolines employing the featured methodology of electrophilic activation of nitroalkanes. To this end, $\alpha$-nitroacetophenone (1g) was subjected to the reaction with ethylenediamines $2 \mathbf{a}$ and 2b under optimized reaction conditions. We were surprised to find that imidazolines $\mathbf{4 f a}$ and $\mathbf{4 f b}$ were obtained in these reactions as sole isolable products (Scheme 6). The yields of these products were quite moderate, but still significantly better than in attempted reactions involving electrophilically activated $\alpha$-nitrotoluene (1f) (Scheme 3, entries 13, 14). Such outcome can be explained as follows (Scheme 6). Although, formation of phosphorylated aci-form of nitroalkanes is thermodynamically favored process, it usually requires quite a long time. With electrophilic carbonyl group already present in the substrate 1g, it easily outcompetes the nitronate site, thus, affording hemiaminal 28. The latter may undergo extrusion of nitromethane to yield carboxamide species 29, which can undergo subsequent 5exo-trig cyclization via "normal" route, affording cyclic

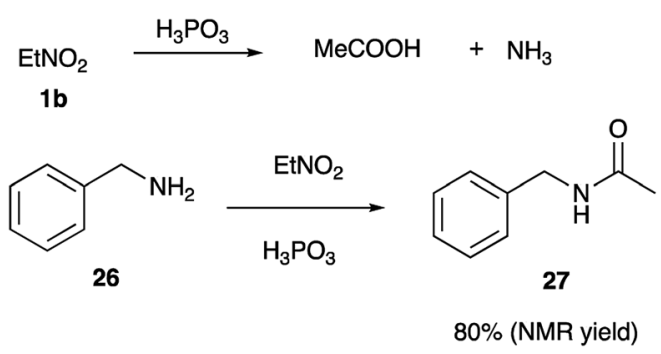

Scheme 5 Reduction of nitroalkanes with $\mathrm{H}_{3} \mathrm{PO}_{3}$.
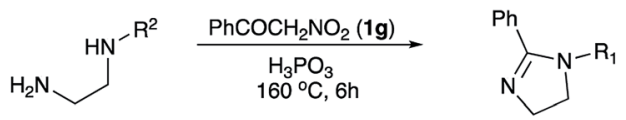

2a: $\mathrm{R}^{2}=\mathrm{Ph}$;

2b: $\mathrm{R}^{2}=4-\mathrm{MeOC}_{6} \mathrm{H}_{4}$

4

2c: $\mathrm{R}^{2}=\mathrm{PhCH}_{2}$<smiles>Pc1ccccc1</smiles><smiles>COCCN1CCN=C1c1ccccc1</smiles>

4fa: $36 \%$

4fb: $41 \%$

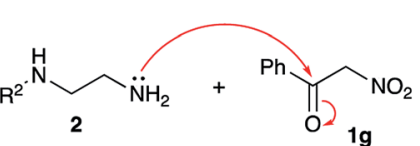

$\underset{-\mathrm{MeNO}_{2}}{\stackrel{+\mathrm{H}^{\oplus}}{\longrightarrow}}$<smiles>[R]NCCNC(=O)c1ccccc1</smiles>

29

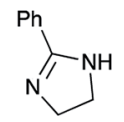

4ff: $38 \%$
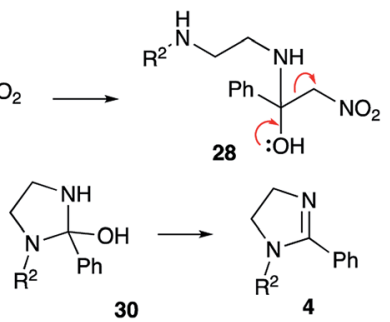

Scheme 6 Synthesis of imidazolines from $\alpha$-nitroacetophenone. intermediate 30. After elimination of water this shall provide imidazoline product $\mathbf{4}$, missing carbonyl group in the substituent at C-2. It should be pointed out, that this pathway, provides an alternative route for installation of bulky substituents at C-2, although it might be less efficient than "normal route", involving direct condensation of diamines with carboxylic acid derivatives. Interestingly, reaction of $\mathrm{N}$-benzyl-1,2ethylenediamine (2c) with $\alpha$-nitroacetophenone $\mathbf{1 g}$ carried at $160{ }^{\circ} \mathrm{C}$ was accompanied by competing debenzylation of the resulting imidazoline. After $12 \mathrm{~h}$ this process was complete affording heterocycle $\mathbf{4 f f}$ as sole product, albeit in modest yield (Scheme 5). Benzyl group is removed in a form of benzyl alcohol (as detected by GC/MS analysis of the crude reaction mixture), which advocates for $\mathrm{S}_{N} 2$-mechanism of this process.

\section{Conclusion}

In conclusion, a new protocol was developed, allowing for an assembly of imidazolines from aliphatic 1,2-diamines and electrophilically activated nitroalkanes. Although preparation of benzimidazoles from aromatic analogs can be performed routinely, reaction of aliphatic bis-nucleophiles required careful optimization of the reaction conditions and switching to quite unusual $\mathrm{H}_{3} \mathrm{PO}_{3}$ reaction medium. Reaction provides quite moderate yields and is very sensitive to steric factors. Several side processes were studied and the plausible mechanistic rationales explaining the observed limitations was suggested.

\section{Experimental part}

\section{General information}

${ }^{1} \mathrm{H}$ and ${ }^{13} \mathrm{C}$ NMR spectra were recorded on a Bruker Avance-III spectrometer (400 or $100 \mathrm{MHz}$, respectively) equipped with a BBO probe in $\mathrm{CDCl}_{3}$ using TMS as an internal standard. Highresolution mass spectra were registered with a Bruker Maxis spectrometer (electrospray ionization, in MeCN solution, using $\mathrm{HCO}_{2} \mathrm{Na}-\mathrm{HCO}_{2} \mathrm{H}$ for calibration). Melting points were measured with a Stuart SMP30 apparatus. All reactions were performed in oven-dried $5 \mathrm{~mL}$ round-bottomed flasks equipped with reflux condensers. The reaction progress and purity of isolated compounds were controlled by TLC on Silufol UV-254 plates, with EtOAc as eluent. Polyphosphoric acids (86\% and $80 \%$ ) were obtained by dissolving of precise amount of $\mathrm{P}_{2} \mathrm{O}_{5}$ in $85 \%$ orthophosphoric acid according to the published protocols. $^{29,30}$ All reagents and solvents were purchased from commercial vendors and used as received.

\section{2-Ethyl-1-phenyl-4,5-dihydro-1H-imidazole (4aa)}

Typical procedure: round bottomed flask ( $5 \mathrm{~mL}$ ) equipped with reflux condenser and magnetic bar was charged with $N$-phenyl1,2-ethylenediamine (2a) $(129 \mu \mathrm{L}, 136 \mathrm{mg}, 1.00 \mathrm{mmol}), 1$-nitropropane (1a) $(179 \mu \mathrm{L}, 178 \mathrm{mg}, 2.00 \mathrm{mmol})$, and phosphorous acid $(500 \mathrm{mg})$. The reaction vessel was placed in the oil bath preheated to $160{ }^{\circ} \mathrm{C}$ and the mixture was stirred for $6 \mathrm{~h}$. Then the mixture was cooled down, quenched with water $(10 \mathrm{~mL})$, and basified with $20 \%$ aqueous ammonia $(10 \mathrm{~mL})$. Crude organic 
material was extracted with dichloromethane $(4 \times 15 \mathrm{~mL})$, concentrated in vacuum and purified with preparative column chromatography on silica gel eluting with acetone/EtOAc/Et ${ }_{3} \mathrm{~N}$ ( $4: 4: 0.3)$. The titled compound was obtained as a yellowish oil, $R_{\mathrm{f}} 0.40$ (acetone/EtOAc/Et ${ }_{3} \mathrm{~N}, 4: 4: 0.5$ ), $R_{\mathrm{f}} 0.37$ (EtOH/ EtOAc/Et $\left.{ }_{3} \mathrm{~N}, 50: 30: 3\right)$. Yield $174 \mathrm{mg}(0.74 \mathrm{mmol}, 74 \%) .{ }^{1} \mathrm{H}$ NMR (400 MHz, $\left.\mathrm{CDCl}_{3}\right): \delta=7.31(\mathrm{t}, J=7.9 \mathrm{~Hz}, 2 \mathrm{H}), 7.14-7.03$ $(\mathrm{m}, 3 \mathrm{H}), 3.78(\mathrm{~s}, 4 \mathrm{H}), 2.28(\mathrm{q}, J=7.4 \mathrm{~Hz}, 2 \mathrm{H}), 1.11(\mathrm{t}, J=7.4 \mathrm{~Hz}$, $3 \mathrm{H}) .{ }^{13} \mathrm{C} \mathrm{NMR}\left(101 \mathrm{MHz}, \mathrm{CDCl}_{3}\right): \delta=166.1,141.7,129.3(2 \mathrm{C})$, 124.6, 123.3 (2C), 52.9, 52.1, 22.2, 11.0. IR (film, NaCl, $\mathrm{cm}^{-1}$ ): 3311, 2982, 2938, 1655, 1607, 1503, 1222, 1069; HRMS (ES TOF) calculated for $\mathrm{C}_{11} \mathrm{H}_{15} \mathrm{~N}_{2}(\mathrm{M}+\mathrm{H})^{+} 175.1230$, found 175.1232 (-1.2 ppm).

\section{2-Ethyl-1-(4-methoxyphenyl)-4,5-dihydro-1H-imidazole (4ab)}

This compound was prepared according to the typical procedure employing $N$-(4-methoxyphenyl)ethylenediamine (2b) (153 $\mu \mathrm{L}, 166 \mathrm{mg}, 1.00 \mathrm{mmol}), 1$-nitropropane (1a) $(179 \mu \mathrm{L}, 178 \mathrm{mg}$, $2.00 \mathrm{mmol}$ ), and phosphorous acid (500 mg). The crude material was purified by preparative column chromatography on silica gel eluting with acetone/EtOAc/ $\mathrm{Et}_{3} \mathrm{~N}(4: 1: 0.3)$. The titled compound was isolated as a yellowish oil, $R_{\mathrm{f}} 0.41$ (acetone/ EtOAc/Et $\left.{ }_{3} \mathrm{~N}, 4: 1: 0.5\right)$. Yield $114 \mathrm{mg}$ (0.56 mmol, $\left.56 \%\right) .{ }^{1} \mathrm{H}$ NMR (400 MHz, $\left.\mathrm{CDCl}_{3}\right): \delta=7.05(\mathrm{~d}, J=8.9 \mathrm{~Hz}, 2 \mathrm{H}), 6.88(\mathrm{~d}, J=$ $8.9 \mathrm{~Hz}, 2 \mathrm{H}), 3.80(\mathrm{~s}, 3 \mathrm{H}), 3.86-3.70(\mathrm{~m}, 4 \mathrm{H}), 2.17$ (q, $J=7.4 \mathrm{~Hz}$, $2 \mathrm{H}), 1.10(\mathrm{t}, J=7.5 \mathrm{~Hz}, 3 \mathrm{H}) .{ }^{13} \mathrm{C} \mathrm{NMR}\left(101 \mathrm{MHz}, \mathrm{CDCl}_{3}\right): \delta=$ 167.6, 157.7, 134.7, 126.5 (2C), 114.7 (2C), 55.6, 54.1, 51.9, 21.7, 10.9. IR (film, $\mathrm{NaCl}, \mathrm{cm}^{-1}$ ): 2985, 2880, 2836, 2368, 1650, 1515, 1240, 1034; HRMS (ES TOF) calculated for $\mathrm{C}_{12} \mathrm{H}_{17} \mathrm{~N}_{2} \mathrm{O}_{1}(\mathrm{M}+\mathrm{H})^{+}$ 205.1335, found $205.1340(-2.2 \mathrm{ppm})$.

\section{1-Benzyl-2-ethyl-4,5-dihydro-1H-imidazole (4ac)}

This compound was prepared according to the typical procedure employing $N$-benzyl-1,2-ethylenediamine (2c) $(151 \mu \mathrm{L}$, $150 \mathrm{mg}, 1.00 \mathrm{mmol}$ ), 1-nitropropane (1a) (179 $\mu \mathrm{L}, 178 \mathrm{mg}, 2.00$ $\mathrm{mmol}$ ), and phosphorous acid (500 $\mathrm{mg})$. The crude material was purified by preparative column chromatography on silica gel eluting with acetone/EtOAc/ $\mathrm{Et}_{3} \mathrm{~N}, \quad 4: 1: 0.3$. The titled compound was isolated as a yellowish oil, $R_{\mathrm{f}} 0.29$ (acetone/ EtOAc/Et $\left.{ }_{3} \mathrm{~N}, 4: 1: 1\right)$. Yield $145 \mathrm{mg}$ (0.77 mmol, 77\%). ${ }^{1} \mathrm{H}$ NMR $\left(400 \mathrm{MHz}, \mathrm{CDCl}_{3}\right): \delta=7.34(\mathrm{t}, J=7.3 \mathrm{~Hz}, 2 \mathrm{H}), 7.30-7.19(\mathrm{~m}, 3 \mathrm{H})$, $4.28(\mathrm{~s}, 2 \mathrm{H}), 3.69(\mathrm{t}, J=9.6 \mathrm{~Hz}, 2 \mathrm{H}), 3.21(\mathrm{t}, J=9.7 \mathrm{~Hz}, 2 \mathrm{H}), 2.31$ (q, $J=7.3 \mathrm{~Hz}, 2 \mathrm{H}), 1.23(\mathrm{t}, J=7.4 \mathrm{~Hz}, 3 \mathrm{H}) .{ }^{13} \mathrm{C}$ NMR $(101 \mathrm{MHz}$, $\left.\mathrm{CDCl}_{3}\right): \delta=168.3,137.8,128.8$ (2C), 127.5, 127.3 (2C), 52.1, 50.6, $50.4,21.2$, 10.9. IR (film, $\mathrm{NaCl}, \mathrm{cm}^{-1}$ ): 3307, 2974, 2938, 2882, 1743, 1655, 1563, 1515, 1459, 1382, 1246; HRMS (ES TOF) calculated for $\mathrm{C}_{12} \mathrm{H}_{17} \mathrm{~N}_{2}(\mathrm{M}+\mathrm{H})^{+}$189.1386, found 189.1384 (1.3 ppm).

\section{2-Ethyl-5-methyl-4,5-dihydro-1 $\mathrm{H}$-imidazole (4ad)}

This compound was prepared according to the typical procedure employing $( \pm)$-1,2-diaminopropane (2d) (82 $\mu \mathrm{L}, 74 \mathrm{mg}$, $1.00 \mathrm{mmol}), 1$-nitropropane (1a) $(179 \mu \mathrm{L}, 178 \mathrm{mg}, 2.00 \mathrm{mmol})$, and phosphorous acid (500 mg). The crude material was purified by preparative column chromatography on silica gel eluting first with acetone/EtOAc/Et ${ }_{3} \mathrm{~N}(40: 17: 3)$ and acetone/ $\mathrm{Et}_{3} \mathrm{~N}$
(3:1) to remove impurities following by acetone $/ 20 \%$ aq. ammonia to collect the target molecule. The titled compound was isolated as a yellowish oil, $R_{\mathrm{f}} 0.55$ (acetone/aq. (20\%) $\left.\mathrm{NH}_{4} \mathrm{OH}, 10: 2\right)$. Yield $42 \mathrm{mg}(0.38 \mathrm{mmol}, 38 \%) .{ }^{1} \mathrm{H}$ NMR (400 $\left.\mathrm{MHz}_{\mathrm{CDCl}}\right): \delta=4.14-3.98(\mathrm{~m}, 1 \mathrm{H}), 3.78(\mathrm{t}, J=10.7 \mathrm{~Hz}, 1 \mathrm{H})$, $3.24(\mathrm{dd}, J=11.3,7.5 \mathrm{~Hz}, 1 \mathrm{H}), 2.37$ (q, $J=7.6 \mathrm{~Hz}, 2 \mathrm{H}), 1.24$ (d, $J$ $=6.3 \mathrm{~Hz}, 3 \mathrm{H}), 1.19(\mathrm{t}, J=7.6 \mathrm{~Hz}, 3 \mathrm{H}) .{ }^{13} \mathrm{C} \mathrm{NMR}(101 \mathrm{MHz}$, $\mathrm{CDCl}_{3}$ ): $\delta=171.4,53.5,52.2,21.4,20.4,10.7$. IR (film, $\mathrm{NaCl}, \mathrm{cm}^{-1}$ ): 3239, 2974, 2934, 2886, 1747, 1659, 1563, 1402, 1286; HRMS (ES TOF) calculated for $\mathrm{C}_{6} \mathrm{H}_{13} \mathrm{~N}_{2}(\mathrm{M}+\mathrm{H})^{+}$113.1073, found $113.1074(-0.3 \mathrm{ppm})$.

\section{2-Ethyl-1,5-diphenyl-4,5-dihydro-1 $\mathrm{H}$-imidazole (4ae)}

This compound was prepared according to the typical procedure employing $N$-1,1-diphenyl-1,2-ethanediamine (2e), $(190 \mu \mathrm{L}$, $212 \mathrm{mg}, 1.00 \mathrm{mmol}$ ), 1-nitropropane (1a) (179 $\mathrm{L}$, $178 \mathrm{mg}, 2.00$ $\mathrm{mmol}$ ), and phosphorous acid (500 $\mathrm{mg})$. The crude material was purified by preparative column chromatography on silica gel eluting with EtOAc/hexanes $(1: 1)$. The titled compound was isolated as a yellowish oil, $R_{\mathrm{f}} 0.33$ (EtOAc/hexanes, $1: 1$ ). Yield $93 \mathrm{mg}(0.37 \mathrm{mmol}, 37 \%) .{ }^{1} \mathrm{H}$ NMR (400 MHz, $\left.\mathrm{CDCl}_{3}\right): \delta=7.34-$ $7.19(\mathrm{~m}, 7 \mathrm{H}), 7.13(\mathrm{t}, J=7.4 \mathrm{~Hz}, 1 \mathrm{H}), 6.98(\mathrm{~d}, J=7.6 \mathrm{~Hz}, 2 \mathrm{H}), 5.08$ $(\mathrm{t}, J=10.2 \mathrm{~Hz}, 1 \mathrm{H}), 4.36(\mathrm{dd}, J=13.9,10.9 \mathrm{~Hz}, 1 \mathrm{H}), 3.76(\mathrm{dd}, J=$ 14.0, $9.7 \mathrm{~Hz}, 1 \mathrm{H}), 2.45-2.23(\mathrm{~m}, 2 \mathrm{H}), 1.19(\mathrm{t}, J=7.5 \mathrm{~Hz}, 3 \mathrm{H}) .{ }^{13} \mathrm{C}$ NMR (101 MHz, $\mathrm{CDCl}_{3}$ ): $\delta=167.5,141.6,140.2,129.4$ (2C), 128.9 (2C), 128.0, 127.2 (2C), 126.4, 125.9 (2C), 69.3, 61.7, 22.2, 11.0. IR (film, $\mathrm{NaCl}, \mathrm{cm}^{-1}$ ): 3375, 2934, 2365, 1603, 1493, 1390, 1222, 1029; HRMS (ES TOF) calculated for $\mathrm{C}_{17} \mathrm{H}_{19} \mathrm{~N}_{2}(\mathrm{M}+\mathrm{H})^{+}$ 251.1543, found $251.1550(-2.8 \mathrm{ppm})$.

\section{2-Methyl-1-phenyl-4,5-dihydro-1H-imidazole (4ba)}

This compound was prepared according to the typical procedure employing $N$-phenyl-1,2-ethylenediamine (2a) $(129 \mu \mathrm{L}$, $136 \mathrm{mg}, 1.00 \mathrm{mmol}$ ), nitroethane (1b) (144 $\mathrm{L}$, $150 \mathrm{mg}, 2.00$ $\mathrm{mmol}$ ), and phosphorous acid (500 $\mathrm{mg})$. The crude material was purified by preparative column chromatography on silica gel eluting with acetone/EtOAc/Et ${ }_{3} \mathrm{~N}, \quad(4: 4: 0.3)$. The titled compound was isolated as a yellowish oil, $R_{\mathrm{f}} 0.14$ (acetone/ EtOAc/Et ${ }_{3} \mathrm{~N}, 4: 4: 0.5$ ), $R_{\mathrm{f}} 0.37$ (acetone/EtOAc/Et ${ }_{3} \mathrm{~N}, 4: 1: 1$ ). Yield $99 \mathrm{mg}$ (0.62 mmol, 62\%). ${ }^{1} \mathrm{H} \mathrm{NMR}\left(400 \mathrm{MHz}, \mathrm{CDCl}_{3}\right): \delta=$ $7.30(\mathrm{t}, J=7.8 \mathrm{~Hz}, 2 \mathrm{H}), 7.06(\mathrm{dd}, J=17.1,7.7 \mathrm{~Hz}, 3 \mathrm{H}), 3.85-3.67$ $(\mathrm{m}, 4 \mathrm{H}), 2.00(\mathrm{~s}, 3 \mathrm{H}) .{ }^{13} \mathrm{C}$ NMR (101 MHz, $\left.\mathrm{CDCl}_{3}\right): \delta=161.5$, 141.5, 129.2 (2C), 124.1, 122.2 (2C), 52.1, 51.9, 16.0. IR (film, $\left.\mathrm{NaCl}, \mathrm{cm}^{-1}\right): 3291,3042,2938,2862,1650,1599,1402,1318$, 1258, 1041; HRMS (ES TOF) calculated for $\mathrm{C}_{10} \mathrm{H}_{13} \mathrm{~N}_{2}(\mathrm{M}+\mathrm{H})^{+}$ 161.1073, found 161.1077 (-2.4 ppm).

\section{1-(4-Methoxyphenyl)-2-methyl-4,5-dihydro-1 $H$-imidazole (4bb)}

This compound was prepared according to the typical procedure employing $N$-(4-methoxyphenyl)ethylenediamine (2b) (153 $\mu \mathrm{L}, 166 \mathrm{mg}, 1.00 \mathrm{mmol}$ ), nitroethane (1b) (144 $\mu \mathrm{L}, 150 \mathrm{mg}, 2.00$ $\mathrm{mmol}$ ), and phosphorous acid (500 $\mathrm{mg})$. The crude material was purified by preparative column chromatography on silica gel eluting with acetone/EtOAc/ $\mathrm{Et}_{3} \mathrm{~N} \quad(4: 1: 0.3)$. The titled compound was isolated as a yellowish oil, $R_{\mathrm{f}} 0.24$ (acetone/ EtOAc/ $\left.\mathrm{Et}_{3} \mathrm{~N}, 4: 1: 0.5\right)$. Yield $80 \mathrm{mg}$ (0.42 mmol, 42\%). ${ }^{1} \mathrm{H}$ NMR 
$\left(400 \mathrm{MHz}, \mathrm{CDCl}_{3}\right): \delta=7.06(\mathrm{~d}, J=8.9 \mathrm{~Hz}, 2 \mathrm{H}), 6.95-6.86(\mathrm{~m}$, 2H), 3.81 (s, 3H), 3.81-3.72 (m, 4H), 1.91 (s, 3H). ${ }^{13} \mathrm{C}$ NMR (101 $\mathrm{MHz}, \mathrm{CDCl}_{3}$ ): $\delta=163.0,157.4,134.6,125.7$ (2C), 114.6 (2C), 55.6, 53.4, 51.8, 15.2. IR (film, $\mathrm{NaCl}, \mathrm{cm}^{-1}$ ): 3059, 2989, 2836, 2363, 1615, 1506, 1401, 1244, 1183; HRMS (ES TOF) calculated for $\mathrm{C}_{11} \mathrm{H}_{15} \mathrm{~N}_{2} \mathrm{O}_{1}(\mathrm{M}+\mathrm{H})^{+}$191.1179, found 191.1174 (2.6 ppm).

\section{1-Benzyl-2-methyl-4,5-dihydro-1H-imidazole (4bc)}

This compound was prepared according to the typical procedure employing $N$-benzyl-1,2-ethylenediamine (2c) $(151 \mu \mathrm{L}$, $150 \mathrm{mg}, 1.00 \mathrm{mmol})$, nitroethane (1b) (144 $\mu \mathrm{L}, 150 \mathrm{mg}, 2.00$ $\mathrm{mmol}$ ), and phosphorous acid (500 $\mathrm{mg})$. The crude material was purified by preparative column chromatography on silica gel eluting with $\mathrm{EtOH} / \mathrm{EtOAc} / \mathrm{Et}_{3} \mathrm{~N}(5: 3: 1)$. The titled compound was isolated as a yellowish oil, $R_{\mathrm{f}} 0.43\left(\mathrm{EtOAc} / \mathrm{Et}_{3} \mathrm{~N}, 10: 1\right)$. Yield $103 \mathrm{mg}$ (0.59 mmol, 59\%). ${ }^{1} \mathrm{H}$ NMR (400 MHz, $\left.\mathrm{CDCl}_{3}\right): \delta=7.43-$ $7.27(\mathrm{~m}, 3 \mathrm{H}), 7.22(\mathrm{~d}, J=7.0 \mathrm{~Hz}, 2 \mathrm{H}), 4.33(\mathrm{~s}, 2 \mathrm{H}), 3.72(\mathrm{t}, J=$ $9.8 \mathrm{~Hz}, 2 \mathrm{H}), 3.30(\mathrm{t}, J=9.7 \mathrm{~Hz}, 2 \mathrm{H}), 2.10(\mathrm{~s}, 3 \mathrm{H}) .{ }^{13} \mathrm{C} \mathrm{NMR}(101$ $\mathrm{MHz}, \mathrm{CDCl}_{3}$ ): $\delta=165.1,136.6,129.1$ (2C), 128.0, 127.4 (2C), 50.7, 50.0, 49.8, 14.0. IR (film, $\mathrm{NaCl}, \mathrm{cm}^{-1}$ ): 3030, 2870, 2834, 2361, 1619, 1495, 1418, 1274, 1250, 1029; HRMS (ES TOF) calculated for $\mathrm{C}_{11} \mathrm{H}_{15} \mathrm{~N}_{2}(\mathrm{M}+\mathrm{H})^{+} 175.1230$, found 175.1232 $(-1.2 \mathrm{ppm})$.

\section{1-Phenyl-4,5-dihydro-1 $\mathrm{H}$-imidazole (4ca)}

This compound was prepared according to the typical procedure employing $N$-phenyl-1,2-ethylenediamine (2a) $(129 \mu \mathrm{L}$, $136 \mathrm{mg}, 1.00 \mathrm{mmol})$, nitromethane (1c) $(269 \mu \mathrm{L}, 305 \mathrm{mg}, 5.00$ $\mathrm{mmol}$ ), and phosphorous acid (500 $\mathrm{mg})$. The crude material was purified by preparative column chromatography on silica gel eluting with acetone/EtOAc/Et ${ }_{3} \mathrm{~N} \quad(1: 6: 0.3)$. The titled compound was isolated as a yellowish oil, $R_{\mathrm{f}} 0.36$ (acetone/ EtOAc/Et $\left.{ }_{3} \mathrm{~N}, 1: 6: 0.5\right)$. Yield $41 \mathrm{mg}(0.28 \mathrm{mmol}, 28 \%) .{ }^{1} \mathrm{H}$ NMR $\left(400 \mathrm{MHz}, \mathrm{CDCl}_{3}\right): \delta=8.22(\mathrm{~s}, 1 \mathrm{H}), 7.19(\mathrm{t}, J=7.9 \mathrm{~Hz}, 2 \mathrm{H}), 6.73$ $(\mathrm{t}, J=7.3 \mathrm{~Hz}, 1 \mathrm{H}), 6.63(\mathrm{~d}, J=7.7 \mathrm{~Hz}, 2 \mathrm{H}), 3.56(\mathrm{dd}, J=11.6$, $5.9 \mathrm{~Hz}, 2 \mathrm{H}), 3.33(\mathrm{t}, J=5.8 \mathrm{~Hz}, 2 \mathrm{H}) .{ }^{13} \mathrm{C} \mathrm{NMR}\left(101 \mathrm{MHz}, \mathrm{CDCl}_{3}\right)$ : $\delta=161.9$, 147.9, 129.5 (2C), 118.1, 113.0 (2C), 43.9, 37.9. IR (film, $\mathrm{NaCl}, \mathrm{cm}^{-1}$ ): 3351, 3054, 2874, 1663, 1603, 1507, 1386, 1326, 1254, 877, 753; HRMS (ES TOF) calculated for $\mathrm{C}_{9} \mathrm{H}_{11} \mathrm{~N}_{2}(\mathrm{M}$ $+\mathrm{H})^{+}$147.0917, found $147.0920(-2.4 \mathrm{ppm})$.

\section{2-Heptyl-1-(4-methoxyphenyl)-4,5-dihydro-1 $\mathrm{H}$-imidazole (4db)}

This compound was prepared according to the typical procedure employing $N$-(4-methoxyphenyl)ethylenediamine (2b) (153 $\mu \mathrm{L}, 166 \mathrm{mg}, 1.00 \mathrm{mmol}), 1$-nitrooctane (1d) $(346 \mu \mathrm{L}, 318 \mathrm{mg}$, $2.00 \mathrm{mmol}$ ), and phosphorous acid $(500 \mathrm{mg})$. The crude material was purified by preparative column chromatography on silica gel eluting with hexanes/EtOAc/EtOH/Et ${ }_{3} \mathrm{~N}, 10: 1: 1: 1$. The titled compound was isolated as a yellowish oil, $R_{\mathrm{f}} 0.68$ (hexanes/EtOAc/EtOH/Et ${ }_{3} \mathrm{~N}, \quad 6: 1: 1: 1$ ). Yield $145 \mathrm{mg}$ (0.53 mmol, 53\%). ${ }^{1} \mathrm{H}$ NMR (400 MHz, $\left.\mathrm{CDCl}_{3}\right): \delta=7.06(\mathrm{~d}, J=$ $8.9 \mathrm{~Hz}, 2 \mathrm{H}), 6.90(\mathrm{~d}, J=8.8 \mathrm{~Hz}, 2 \mathrm{H}), 3.92-3.70(\mathrm{~m}, 7 \mathrm{H}), 2.24-2.15$ (m, 2H), 1.59-1.49 (m, 2H), 1.30-1.11 (m, 8H), $0.83(\mathrm{t}, J=6.8 \mathrm{~Hz}$, $3 \mathrm{H}) .{ }^{13} \mathrm{C} \mathrm{NMR}\left(101 \mathrm{MHz}, \mathrm{CDCl}_{3}\right): \delta=167.4,158.1,133.8,126.7$ (2C), 114.8 (2C), 55.6, 54.06, 50.6, 31.7, 29.4, 28.9, 27.9, 26.6, 22.7, 14.2. IR (film, $\mathrm{NaCl}, \mathrm{cm}^{-1}$ ): 2954, 2871, 2840, 1616, 1511,
1458, 1380, 1244, 1043; HRMS (ES TOF) calculated for $\mathrm{C}_{17} \mathrm{H}_{27} \mathrm{~N}_{2} \mathrm{O}_{1}(\mathrm{M}+\mathrm{H})^{+}$275.2118, found 285.2113 (2.0 ppm).

\section{2-Heptyl-5-methyl-4,5-dihydro-1H-imidazole (4dd)}

This compound was prepared according to the typical procedure employing $( \pm)$-1,2-diaminopropane (2d) $(82 \mu \mathrm{L}, 74 \mathrm{mg}$, $1.00 \mathrm{mmol}), 1$-nitrooctane (1d) $(346 \mu \mathrm{L}, 318 \mathrm{mg}, 2.00 \mathrm{mmol})$, and phosphorous acid $(500 \mathrm{mg})$. The crude material was purified by preparative column chromatography on silica gel eluting first with acetone/ $\mathrm{Et}_{3} \mathrm{~N}(9: 1)$ to remove impurities following by acetone $/ 20 \%$ aq. ammonia $(6: 1)$ to collect the target molecule. The titled compound was isolated as a yellowish oil, $R_{\mathrm{f}} 0.37$ (acetone $\left./ \mathrm{Et}_{3} \mathrm{~N}, 10: 1\right)$. Yield $78 \mathrm{mg}$ (0.43 mmol, 43\%). ${ }^{1} \mathrm{H} \mathrm{NMR}$ $\left(400 \mathrm{MHz}, \mathrm{CDCl}_{3}\right): \delta=4.01-3.84(\mathrm{~m}, 1 \mathrm{H}), 3.70(\mathrm{t}, J=10.5 \mathrm{~Hz}$, $1 \mathrm{H}), 3.15$ (dd, $J=11.2,7.3 \mathrm{~Hz}, 1 \mathrm{H}), 2.22(\mathrm{t}, J=7.8 \mathrm{~Hz}, 2 \mathrm{H}), 1.57$ $(\mathrm{dd}, J=14.6,7.1 \mathrm{~Hz}, 2 \mathrm{H}), 1.33-1.21(\mathrm{~m}, 8 \mathrm{H}), 1.18(\mathrm{~d}, J=6.3 \mathrm{~Hz}$, $3 \mathrm{H}), 0.84(\mathrm{t}, J=6.4 \mathrm{~Hz}, 3 \mathrm{H}) .{ }^{13} \mathrm{C} \mathrm{NMR}\left(101 \mathrm{MHz}, \mathrm{CDCl}_{3}\right): \delta=$ 167.3, 56.7, 56.2, 31.8, 29.4, 29.3, 29.1, 26.8, 22.7, 21.9, 14.2. IR (film, NaCl, $\mathrm{cm}^{-1}$ ): 2938, 2862, 1711, 1559, 1402, 1250, 1009; HRMS (ES TOF) calculated for $\mathrm{C}_{11} \mathrm{H}_{23} \mathrm{~N}_{2}(\mathrm{M}+\mathrm{H})^{+}$183.1856, found $183.1854(0.8 \mathrm{ppm})$.

\section{2-Benzyl-1-phenyl-4,5-dihydro-1 $H$-imidazole (4ea)}

This compound was prepared according to the typical procedure employing $N$-phenyl-1,2-ethylenediamine (2a) $(129 \mu \mathrm{L}$, $136 \mathrm{mg}, 1.00 \mathrm{mmol})$, 1-phenyl-2-nitroethane (1e) $(269 \mu \mathrm{L}$, $302 \mathrm{mg}, 2.00 \mathrm{mmol}$ ), and phosphorous acid (500 mg). The crude material was purified by preparative column chromatography on silica gel eluting with EtOAc/hexanes $/ \mathrm{Et}_{3} \mathrm{~N}(4: 4: 0.5)$. The titled compound was isolated as a yellowish oil, $R_{\mathrm{f}} 0.28$ (EtOAc/ hexanes/Et $\left.{ }_{3} \mathrm{~N}, 4: 4: 0.5\right)$. Yield $97 \mathrm{mg}$ (0.41 mmol, $\left.41 \%\right) .{ }^{1} \mathrm{H}$ NMR (400 MHz, $\left.\mathrm{CDCl}_{3}\right): \delta=7.31(\mathrm{t}, J=7.8 \mathrm{~Hz}, 2 \mathrm{H}), 7.25-7.13$ (m, 4H), 7.11 (d, $J=6.7 \mathrm{~Hz}, 2 \mathrm{H}), 7.06-6.99(\mathrm{~m}, 2 \mathrm{H}), 3.93-3.79$ $(\mathrm{m}, 4 \mathrm{H}), 3.66(\mathrm{~s}, 2 \mathrm{H}) \cdot{ }^{13} \mathrm{C}$ NMR $\left(101 \mathrm{MHz}, \mathrm{CDCl}_{3}\right): \delta=164.2$, 141.2, 136.0, 129.4 (2C), 128.9 (2C), 128.5 (2C), 126.8, 125.6, 124.4 (2C), 53.3, 51.8, 34.6. IR (film, NaCl, $\mathrm{cm}^{-1}$ ): 3323, 3042, 2942, 1651, 1603, 1499, 1262; HRMS (ES TOF) calculated for $\mathrm{C}_{16} \mathrm{H}_{17} \mathrm{~N}_{2}(\mathrm{M}+\mathrm{H})^{+}$237.1386, found 237.1391 (-2.2 ppm).

\section{1,2-Diphenyl-4,5-dihydro-1 $\mathrm{H}$-imidazole (4fa)}

This compound was prepared according to the typical procedure employing $N$-phenyl-1,2-ethylenediamine (2a) $(129 \mu \mathrm{L}$, $136 \mathrm{mg}, 1.00 \mathrm{mmol}), \alpha$-nitrotoluene (1f) $(274 \mathrm{mg}, 2.00 \mathrm{mmol})$, and phosphorous acid $(500 \mathrm{mg})$. The crude material was purified by preparative column chromatography on silica gel eluting with acetone/EtOAc/ $\mathrm{Et}_{3} \mathrm{~N}(1: 8: 0.3)$. The titled compound was isolated as a yellowish oil, $R_{\mathrm{f}} 0.41$ (acetone/EtOAc/Et ${ }_{3} \mathrm{~N}$, 1 : $8: 0.3)$. Yield $40 \mathrm{mg}(0.18 \mathrm{mmol}, 18 \%) .{ }^{1} \mathrm{H}$ NMR $(400 \mathrm{MHz}$, $\left.\mathrm{CDCl}_{3}\right): \delta=7.51-7.45(\mathrm{~m}, 2 \mathrm{H}), 7.38-7.32(\mathrm{~m}, 1 \mathrm{H}), 7.30-7.24(\mathrm{~m}$, $2 \mathrm{H}), 7.16(\mathrm{t}, J=7.9 \mathrm{~Hz}, 2 \mathrm{H}), 6.98(\mathrm{t}, J=7.4 \mathrm{~Hz}, 1 \mathrm{H}), 6.79(\mathrm{~d}, J=$ $7.6 \mathrm{~Hz}, 2 \mathrm{H}), 4.04(\mathrm{~s}, 4 \mathrm{H}) .{ }^{13} \mathrm{C}$ NMR $\left(101 \mathrm{MHz}, \mathrm{CDCl}_{3}\right): \delta=162.7$, 143.1, 131.1, 130.1, 128.8 (2C), 128.8 (2C), 128.3 (2C), 123.5, 122.7 (2C), 54.1, 53.0. IR (film, NaCl, $\mathrm{cm}^{-1}$ ): 3299, 3050, 2946, 2862, 1599, 1495, 1386, 1270; HRMS (ES TOF) calculated for $\mathrm{C}_{15} \mathrm{H}_{15} \mathrm{~N}_{2}(\mathrm{M}+\mathrm{H})^{+}$223.1230, found $223.1233(-1.2 \mathrm{ppm})$. 
The same material was obtained employing $\alpha$-nitroacetophenone $(\mathbf{1 g})(330 \mathrm{mg}, 2.00 \mathrm{mmol})$ instead of $\alpha$-nitrotoluene (1f). Yield $80 \mathrm{mg}(0.36 \mathrm{mmol}, 36 \%)$.

\section{1-(4-Methoxyphenyl)-2-phenyl-4,5-dihydro-1 $H$-imidazole (4fb)}

This compound was prepared according to the typical procedure employing $N$-(4-methoxyphenyl)ethylenediamine (2b) (153 $\mu \mathrm{L}, 166 \mathrm{mg}, 1.00 \mathrm{mmol}), \alpha$-nitrotoluene (1f) $(274 \mathrm{mg}, 2.00$ $\mathrm{mmol}$ ), and phosphorous acid (500 $\mathrm{mg}$ ). The crude material was purified by preparative column chromatography on silica gel eluting with acetone/EtOAc/Et ${ }_{3} \mathrm{~N} \quad(1: 8: 0.3)$. The titled compound was isolated as a yellowish oil, $R_{\mathrm{f}} 0.35$ (acetone/ EtOAc/Et $\left.{ }_{3} \mathrm{~N}, 1: 8: 0.3\right) ; R_{\mathrm{f}} 0.25$ (EtOAc/EtOH $1: 1$ ); $R_{\mathrm{f}} 0.57$ (acetone/EtOAc/Et $\left.{ }_{3} \mathrm{~N}, 4: 4: 0.5\right)$. Yield $40 \mathrm{mg}(0.16 \mathrm{mmol}, 16 \%)$. ${ }^{1} \mathrm{H}$ NMR $\left(400 \mathrm{MHz}, \mathrm{CDCl}_{3}\right): \delta=7.50(\mathrm{~d}, J=7.3 \mathrm{~Hz}, 2 \mathrm{H}), 7.37(\mathrm{t}, J$ $=7.4 \mathrm{~Hz}, 1 \mathrm{H}), 7.29(\mathrm{~d}, J=7.7 \mathrm{~Hz}, 2 \mathrm{H}), 6.87(\mathrm{~d}, J=8.9 \mathrm{~Hz}, 2 \mathrm{H})$, $6.76(\mathrm{~d}, J=8.9 \mathrm{~Hz}, 2 \mathrm{H}), 4.14-4.05(\mathrm{~m}, 4 \mathrm{H}), 3.75(\mathrm{~s}, 3 \mathrm{H}) .{ }^{13} \mathrm{C}$ NMR $\left(101 \mathrm{MHz}, \mathrm{CDCl}_{3}\right): \delta=164.1,157.4,134.9,131.1,129.2$ (2C), 128.53, 128.47 (2C), 125.8 (2C), 114.6 (2C), 55.6, 55.2, 50.4. IR (film, $\mathrm{NaCl}, \mathrm{cm}^{-1}$ ): 3002, 2840, 2363, 1615, 1511, 1388, 1248, 1179, 1039; HRMS (ES TOF) calculated for $\mathrm{C}_{16} \mathrm{H}_{17} \mathrm{~N}_{2} \mathrm{O}_{1}(\mathrm{M}+\mathrm{H})^{+}$ 253.1335, found 253.1339 (-1.5 ppm).

The same material was obtained employing $\alpha$-nitroacetophenone $(\mathbf{1 g})(330 \mathrm{mg}, 2.00 \mathrm{mmol})$ instead of $\alpha$-nitrotoluene (1f). Yield $103 \mathrm{mg}$ (0.41 mmol, 41\%).

\section{2-Phenyl-4,5-dihydro-1H-imidazole (4ff)}

This compound was prepared according to the typical procedure employing $N$-benzyl-1,2-ethylenediamine (2c) $(151 \mu \mathrm{L}$, $150 \mathrm{mg}, 1.00 \mathrm{mmol}), \alpha$-nitroacetophenone $(\mathbf{1 g})(330 \mathrm{mg}, 2.00$ $\mathrm{mmol}$ ), and phosphorous acid (500 $\mathrm{mg}$ ). The crude material was purified by preparative column chromatography on silica gel eluting with acetone/EtOAc/ $/ \mathrm{Et}_{3} \mathrm{~N} \quad(4: 4: 0.3)$. The titled compound was isolated as a yellowish oil, $R_{\mathrm{f}} 0.35$ (acetone/ EtOAc/Et $\left.{ }_{3} \mathrm{~N}, 4: 4: 0.5\right)$. Yield $55 \mathrm{mg}(0.38 \mathrm{mmol}, 38 \%) .{ }^{1} \mathrm{H}$ NMR $\left(400 \mathrm{MHz}, \mathrm{CDCl}_{3}\right): \delta=7.78(\mathrm{~d}, J=7.1 \mathrm{~Hz}, 2 \mathrm{H}), 7.40(\mathrm{dt}, J=23.1$, $7.2 \mathrm{~Hz}, 3 \mathrm{H}), 3.75(\mathrm{~s}, 4 \mathrm{H}) .{ }^{13} \mathrm{C}$ NMR $\left(101 \mathrm{MHz}, \mathrm{CDCl}_{3}\right): \delta=165.0$, 130.9, 130.3, 128.5 (2C), 127.2 (2C), 50.1 (2C). IR (film, $\left.\mathrm{NaCl}, \mathrm{cm}^{-1}\right): 3051,2875,2368,1685,1598,1572,1493,1380$, 1275; HRMS (ES TOF) calculated for $\mathrm{C}_{9} \mathrm{H}_{11} \mathrm{~N}_{2}(\mathrm{M}+\mathrm{H})^{+} 147.0917$, found 147.0919 (-1.5 ppm).

\section{Conflicts of interest}

There are no conflicts to declare.

\section{Acknowledgements}

This work was supported by the Russian Foundation for Basic Research (grant \#19-03-00308a) and grants from the Ministry of Education and Science of the Russian Federation \#4.1196.2017/ 4.6 and $\# 4.4589 .2017 / 6.7$.

\section{Notes and references}

1 D. J. Reis and S. Regunathan, J. Auton. Nerv. Syst., 1998, 72, 80-85.

2 I. F. Musgrave and R. A. Hughes, Ann. N. Y. Acad. Sci., 1999, 881, 301-312.

3 V. Ozola, M. Thorand, M. Diekmann, R. Qurishi, B. Schumacher, K. A. Jacobson and C. E. Muller, Bioorg. Med. Chem., 2003, 11, 347-356.

4 I. H. Gilbert, D. C. Rees, A. K. Crockett and R. C. F. Jones, Tetrahedron, 1995, 51, 6315-6336.

5 I. K. Khanna, R. M. Weier, Y. Yu, X. D. Xu, F. J. Koszyk, P. W. Collins, C. M. Koboldt, A. W. Veenhuizen, W. E. Perkins, J. J. Casler, J. L. Masferrer, Y. Y. Zhang, S. A. Gregory, K. Seibert and P. C. Isakson, J. Med. Chem., 1997, 40, 1634-1647.

6 R. Gust, R. Keilitz and K. Schmidt, J. Med. Chem., 2001, 44, 1963-1970.

7 M. Mor, F. Bordi, C. Silva, S. Rivara, V. Zuliani, F. Vacondio, G. Morini, E. Barocelli, V. Ballabeni, M. Impicciatore and P. V. Plazzi, Farmaco, 2000, 55, 27-34.

8 V. Sharma, T. A. Lansdell, S. Peddibhotla and J. J. Tepe, Chem. Biol., 2004, 11, 1689-1699.

9 L. M. Azevedo, T. A. Lansdell, J. R. Ludwig, R. A. Mosey, D. K. Woloch, D. P. Cogan, G. P. Patten, M. R. Kuszpit, J. S. Fisk and J. J. Tepe, J. Med. Chem., 2013, 56, 5974-5978.

10 G. A. Boswell, H.-Y. Li, I. Delucca, J. T. Billheimer, S. Drummond, P. J. Gillies and C. Robinson, Bioorg. Med. Chem. Lett., 1996, 6, 885-888.

11 M. Krasavin, Eur. J. Med. Chem., 2015, 97, 525-537.

12 M. Krasavin, Chem. Heterocycl. Compd., 2017, 53, 240-255.

13 Y. V. Popov, V. M. Mokhov and I. I. Kalitina, Russ. J. Gen. Chem., 2016, 86, 281-285.

14 Y. Liu, H. He, B.-F. Yang, Q. Zhang and G.-Y. Yang, J. Cluster Sci., 2015, 26, 1537-1545.

15 X. Sun, J. Qiu, S. A. Strong, L. S. Green, J. W. F. Wasley, J. P. Blonder, D. B. Colagiovanni, S. C. Mutka, A. M. Stout, J. P. Richards and G. J. Rosenthal, Bioorg. Med. Chem. Lett., 2011, 21, 5849-5853.

16 J. H. Forsberg, V. T. Spaziano, T. M. Balasubramanian, G. K. Liu, S. A. Kinsley, C. A. Duckworth, J. J. Poteruca, P. S. Brown and J. L. Miller, J. Org. Chem., 1987, 52, 10171021.

17 A. V. Aksenov, N. A. Aksenov, O. N. Nadein and I. V. Aksenova, Synlett, 2010, 2628-2630.

18 N. A. Aksenov, A. V. Aksenov, O. N. Nadein, D. A. Aksenov, A. N. Smirnov and M. Rubin, $R S C$ Adv. , 2015, 5, 71620-71626.

19 A. V. Aksenov, N. A. Aksenov, N. A. Orazova, D. A. Aksenov, M. V. Dmitriev and M. Rubin, RSC Adv., 2015, 5, 8484984855.

20 A. V. Aksenov, A. N. Smirnov, N. A. Aksenov, A. S. Bijieva, I. V. Aksenova and M. Rubin, Org. Biomol. Chem., 2015, 13, 4289-4295.

21 A. V. Aksenov, N. A. Aksenov, D. S. Ovcharov, D. A. Aksenov, G. Griaznov, L. G. Voskressensky and M. Rubin, RSC Adv., 2016, 6, 82425-82431. 
22 A. V. Aksenov, D. S. Ovcharov, N. A. Aksenov, D. A. Aksenov, O. N. Nadein and M. Rubin, RSC Adv., 2017, 7, 29927-29932. 23 A. V. Aksenov, N. A. Aksenov, D. S. Ovcharov, S. V. Shcherbakov, A. N. Smirnova, I. V. Aksenova, V. I. Goncharov and M. A. Rubin, Russ. J. Org. Chem., 2017, 53, 1081-1084.

24 A. V. Aksenov, V. Khamraev, N. A. Aksenov, N. K. Kirilov, D. A. Domenyuk, V. A. Zelensky and M. Rubin, RSC Adv., 2019, 9, 6636-6642.
25 J. U. Nef, Justus Liebigs Ann. Chem., 1894, 280, 263-291.

26 R. Ballini and M. Petrini, Adv. Synth. Catal., 2015, 357, 23712402.

27 R. Ballini and M. Petrini, Tetrahedron, 2004, 60, 1017-1047.

28 A. V. Aksenov, N. A. Aksenov, D. A. Aksenov, V. F. Khamraev and M. Rubin, Chem. Commun., 2018, 54, 13260-13263.

29 A. L. Huhti and P. A. Gartaganis, Can. J. Chem., 1956, 34, 785797.

30 F. Uhlig, Angew. Chem., 1954, 66, 435-436. 